\title{
Live Borrelia burgdorferi Preferentially Activate Interleukin-1 $\beta$ Gene Expression and Protein Synthesis over the Interleukin-1 Receptor Antagonist
}

\author{
Laurie C. Miller, Sana Isa, Edouard Vannier, Kostis Georgilis, Allen C. Steere, and Charles A. Dinarello \\ Departments of Pediatrics and Medicine, New England Medical Center and \\ Tufts University School of Medicine, Boston, Massachusetts 02111
}

\section{Abstract}

Lyme arthritis is one of the few forms of chronic arthritis in which the cause is known with certainty. Because cytokines are thought to contribute to the pathogenesis of chronic arthritis, we investigated the effect of the Lyme disease spirochete, Borrelia burgdorferi, on the gene expression and synthesis of IL-1 $\beta$ and the IL-1 receptor antagonist (IL-1 ra) in human peripheral blood mononuclear cells. Live $B$. burgdorferi induced fivefold more IL-1 $\beta$ than IL-1 $\alpha$ and sevenfold more IL-1 $\beta$ than IL-1ra; LPS or sonicated $B$. burgdorferi induced similar amounts of all three cytokines. This preferential induction of IL-1 $\beta$ was most dramatic in response to a low passage, virulent preparation of $B$. burgdorferi vs. three high passage avirulent strains. No difference in induction of IL-1 ra was seen between these strains. The marked induction of IL-1 $\beta$ was partially diminished by heat-treatment and abrogated by sonication; IL1ra was not affected. This suggested that a membrane component(s) accounted for the preferential induction of IL-1 $\beta$. However, recombinant outer surface protein $\beta$ induced little IL-1 $\beta$. By $4 \mathrm{~h}$ after stimulation, $B$. burgdorferi induced sixfold more IL-1 $\beta$ protein than LPS. In contrast to LPS-induced IL-1 $\beta$ mRNA which reached maximal accumulation after $3 \mathrm{~h}, \boldsymbol{B}$. burgdorferi-induced IL-1 $\beta$ mRNA showed biphasic elevations at 3 and 18 h. B. burgdorferi-induced IL-1ra mRNA peaked at $12 \mathrm{~h}$, whereas LPS-induced IL-1ra mRNA peaked at $9 \mathrm{~h}$. IL-1 $\beta$ synthesis increased in response to increasing numbers of spirochetes, whereas IL-1ra synthesis did not. The preferential induction by $B$. burgdorferi of IL-1 $\beta$ over IL-1 ra is an example of excess agonist over antagonist synthesis induced by a microbial pathogen, and may contribute to the destructive lesion of Lyme arthritis. (J. Clin. Invest. 1992. 90:906-912.) Key words: antagonist $\bullet$ cytokine $\cdot$ lipopolysaccharide $\bullet$ Lyme arthritis

\section{Introduction}

Lyme disease is a multisystem disease caused by infection with the tick-borne spirochete Borrelia burgdorferi (1). Arthritis is a prominent feature of the disorder. Early in the illness, the spirochete probably spreads hematogenously to joints and may cause vague, migratory joint pain. After several months, many

Address reprint requests to Dr. Miller, Box 67, New England Medical Center, 750 Washington Street, Boston, MA 02111.

Received for publication 3 October 1991 and in revised form 21 February 1992.

J. Clin. Invest.

(C) The American Society for Clinical Investigation, Inc.

0021-9738/92/09/0906/07 \$2.00

Volume 90, September 1992, 906-912 patients begin to have brief attacks of arthritis in large joints (2). During the second and third years of illness, a small subset of patients, primarily those with HLA-DR4 or HLA-DR2 (3, 4), develop chronic arthritis which may lead to erosion of cartilage and bone (5). The synovial lesion in these patients is similar to that in rheumatoid arthritis. The development of chronic arthritis coincides with the appearance of a humoral immune response to two prominent outer surface proteins (Osp) ${ }^{1}$ of $B$. burgdorferi, Osp A and B, (6).

Cytokines, in particular interleukin-1 (IL-1) and tumor necrosis factor- $\alpha$ (TNF), are thought to contribute to the pathogenesis of the synovial lesion in rheumatoid arthritis (7-9). The potent biological effects of these cytokines are tightly regulated at many levels, including gene transcription, translation, protein processing and secretion, as well as naturally occurring inhibitors such as the IL-1 receptor antagonist (IL-1 ra) (10, 11) which occupies IL-1 receptors without inducing signal transduction.

Because Lyme arthritis is one of the few forms of chronic inflammatory arthritis in which the cause is known with certainty (1), this illness presents a unique opportunity to study the direct effects of the pathogen on cytokine gene expression. In contrast to IgG, granulocyte/macrophage colony-stimulating factor, and experimental endotoxemia which preferentially induce IL-1 ra (12-15), we now demonstrate that live $B$. burgdorferi preferentially induce synthesis of the agonist IL- $1 \beta$ compared to the antagonist IL-1 ra. This preferential induction was most marked in response to a low-passage, virulent preparation of $B$. burgdorferi. Furthermore, the selective induction of IL- $1 \beta$ appears to reside in a membrane component of $B$. burgdorferi whose activity is partially diminished by heat treatment but abrogated by sonication.

\section{Methods}

Sample collection. Whole heparinized blood was obtained from 23 healthy volunteers, age $22-40 \mathrm{yr}$, who had not ingested nonsteroidal anti-inflammatory drugs (16) within the previous $2 \mathrm{wk}$, and had no history or clinical symptoms suggestive of Lyme disease. The investigation was approved by the Human Investigation Review Board of New England Medical Center. Informed consent was obtained from each donor.

All reagents and glassware were sterile and endotoxin free. Culture media and sterile water used to prepare Ficoll-Hypaque were passed through a hollow-fiber polysulfone capillary ultrafilter to remove microbial products and endotoxin (17). RPMI 1640 was supplemented only with L-glutamine ( $10 \mathrm{mM}$ ) (Gibco Laboratories, Grand Island, NY) and $10 \mathrm{mM}$ Hepes (M.A. Biologicals, Walkersville, MD). No antibiotics were included in any media used. In preliminary experi-

1. Abbreviations used in this paper: HP and LP, high and low passage (strains); Osp, outer surface protein; ra, receptor antagonist; TNF, tumor necrosis factor- $\alpha$. 
ments, the effects on cytokine induction of heat-inactivated $\left(56^{\circ} \mathrm{C}\right.$ for $1 \mathrm{~h}) 10 \%$ FCS (Hyclone Laboratories, Inc., Logan, UT) and $1 \%$ human $A B$ serum were compared. Human serum alone induced IL-1ra, whereas no induction of either IL-1 or IL-1 ra was detected in the presence of $10 \%$ FCS (data not shown). Therefore, for these experiments, FCS was used as a culture supplement.

B. burgdorferi. B. burgdorferi were grown in Barbour-StoennerKelly medium at $32^{\circ} \mathrm{C}$ in a humidified atmosphere containing $5 \%$ $\mathrm{CO}_{2}$. Three different strains were used: 297 , isolated from the cerebrospinal fluid of a patient with Lyme disease; N40, an Ixodes dammini tick midgut isolate; and $\mathrm{G} 39 / 40$, initially isolated from an I. dammini tick, but passaged for many years in the laboratory. Both high-passage (HP) and low-passage (LP) preparations of strain 297 were used; only the LP 297 strain retained infectivity in mouse inoculation studies as previously reported (18). Organisms were used at log phase growth. The spirochetes were pelleted by centrifugation at $10,000 \mathrm{~g}$ for $20 \mathrm{~min}$ at room temperature, then washed three times in RPMI and resuspended at the desired concentration. In some experiments, spirochetes killed by sonication or heat $\left(57^{\circ} \mathrm{C}\right.$ for $2 \mathrm{~h}$ ) were used. After pelleting by centrifugation at $10,000 \mathrm{~g}$ for $20 \mathrm{~min}$ at $4^{\circ} \mathrm{C}$ and four washes in cold

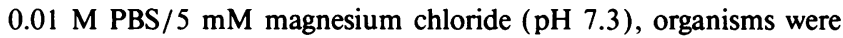
sonicated on ice by eight 15 -s pulses, setting 6 , of a cell sonicator (Branson Sonic Power Co., Danbury, CT). The supernatant was clarified by centrifugation at $10,000 \mathrm{~g}$ for $30 \mathrm{~min}$ at $4^{\circ} \mathrm{C}$; protein content was determined by optical density at $280 \mathrm{~nm}$ in a spectrophotometer (Gilford Instrument Laboratories, Inc., Oberlin, $\mathrm{OH}$ ). Aliquots were stored at $-70^{\circ} \mathrm{C}$. In other experiments, recombinant Osp B protein (a gift of Drs. John Leong and Robert Kalish, New England Medical Center, Boston, MA) was used to stimulate cytokine production from PBMC. To investigate whether a soluble product of $B$. burgdorferi could contribute to the marked induction of IL- $1 \beta$, the spirochetes were extensively washed, then cultured $\left(25 \times 10^{6}\right)$ in antibiotic-free RPMI for 24 $h$ at $37^{\circ} \mathrm{C}$ or $32^{\circ} \mathrm{C}$. After ultracentrifugation, the spirochete-free supernatant was filtered twice through $0.22-\mu \mathrm{m}$ filters. The absence of spirochetes or spirochetal fragments was verified by darkfield microscopy. The spirochete-conditioned media was then incubated with PBMC for $24 \mathrm{~h}$ and resulting cytokine production measured by radioimmunoassays (RIAs).

PBMC cultures. Heparinized whole blood was fractionated by density gradient centrifugation using Ficoll (Sigma Chemical Co., St. Louis, MO)-Hypaque (Winthrop Laboratories, New York, NY). Mononuclear cells were cultured $\left(2.5 \times 10^{6}\right.$ cells $\left./ \mathrm{ml}\right)$ in $1.0 \mathrm{ml}$ of complete RPMI with $10 \%$ heat-inactivated endotoxin-free FCS in 2.5$\mathrm{ml}$ polypropylene tubes (Falcon Plastics, Oxnard, CA) with $B$. burgdorferi or LPS (Escherichia coli 055:B5, Sigma Chemical Co.), or medium alone. Cultures were incubated for $24 \mathrm{~h}$ in a humidified, $5 \% \mathrm{CO}_{2}$ atmosphere at $37^{\circ} \mathrm{C}$. In experiments measuring total cytokine production, cells were lysed by three freeze/thaw cycles (19). After centrifugation at $400 \mathrm{~g}$ for $15 \mathrm{~min}$, the supernatants were removed, and the pellets containing cellular and spirochetal debris were discarded. In experiments measuring secreted vs. cell-associated cytokines, cell-free culture supernatant (containing secreted cytokines) was removed and replaced by an equal volume of fresh media. The cell-containing tubes were then subjected to three freeze/thaw cycles to release cell-associated cytokines, centrifuged at $400 \mathrm{~g}$ for $15 \mathrm{~min}$, and harvested as above.

Cytokine RIAs. Specific RIAs for IL- $1 \beta$, TNF, IL- $1 \alpha$, IL-6, and IL-1 ra were used $(14,19-22)$. Iodination of IL- $1 \beta$ and IL-1 ra used the Bolton-Hunter method; all other cytokines were iodinated by the chloramine-T method. Sensitivities for each of the RIAs was $\leq 80 \mathrm{pg}$ / $\mathrm{ml}$ except for the IL-1 ra RIA which had a sensitivity of $300 \mathrm{pg} / \mathrm{ml}$.

$R N A$ isolation and Northern analysis. After incubation with $B$. burgdorferi (five spirochetes per PBMC), LPS ( $10 \mathrm{ng} / \mathrm{ml}$ ), or control media, total cellular RNA was extracted by lysis with $4 \mathrm{M}$ guanidine isothiocyanate, followed by ultracentrifugation on a $5.7 \mathrm{M}$ cesium chloride cushion. Total RNA $(20 \mu \mathrm{g})$ was subjected to electrophoresis in $6.6 \%$ formaldehyde (Sigma Chemical Co.) and $1.2 \%$ agarose (International Biotechnologies Inc., New Haven, CT), and then transferred to nylon membranes (Hybond-N, Amersham Corp., Arlington Heights,
IL) by capillary blotting. For quantitation of mRNA levels, serial dilutions of RNA $(2.50,1.25$, and $0.62 \mu \mathrm{g})$ were directly applied to nylon membranes using a filtration manifold apparatus (Schleicher \& Schuell, Inc., Keene, NH). The membranes were exposed to shortwave UV light for $5 \mathrm{~min}$ to fix the RNA to the nylon matrix, and treated at $42^{\circ} \mathrm{C}$ for $2 \mathrm{~h}$ with prehybridization solution containing 10 $\mathrm{mg} / \mathrm{ml}$ salmon sperm DNA. Membranes were then treated overnight with prehybridization solution containing $10 \mathrm{mg} / \mathrm{ml}$ of salmon sperm DNA and ${ }^{32} \mathrm{P}$-labeled nucleic acid probe. The probes used were a 1,075 -bp fragment of human IL- $1 \beta$ precursor cDNA subcloned into pGEM2, 800-bp fragment of human IL-1 ra precursor cDNA subcloned into pUC8, and the full length $(2,000$-bp) chicken $\beta$-actin cDNA subcloned in pGEM3. The DNA was labeled using $\left[{ }^{32} \mathrm{P}\right] \mathrm{dCTP}$ (3,000 Ci/mmol, New England Nuclear, Boston, MA) and a random primed DNA labeling kit (Boehringer Mannheim, Mannheim, FRG). After incubation, membranes were washed in $0.1 \%$ SDS, $1 \times$ SSC at $42^{\circ} \mathrm{C}$. Washed membranes were exposed overnight to Kodak KAR5 $\mathrm{X}$-ray film (Eastman Kodak Co., Rochester, NY) at $-70^{\circ} \mathrm{C}$ with an intensifying screen.

Statistical analysis. Total cytokine levels were expressed as mean \pm SEM of the indicated number of donors. Differences were analyzed for significance using Student's $t$ test for paired samples or analysis of variance using the computer program StatView (BrainPower, Inc., Calabasas, CA) on a Macintosh SE computer.

\section{Results}

Cytokine synthesis induced by $B$. burgdorferi. Live B. burgdorferi (297 LP), sonicated B. burgdorferi, and LPS were compared for their ability to induce cytokine synthesis from PBMC (Fig. 1). Live B. burgdorferi induced $65 \pm 11 \mathrm{ng} / \mathrm{ml}$ of IL- $1 \beta$. Large amounts of TNF were also induced $(82 \pm 18 \mathrm{ng} / \mathrm{ml})$, whereas production of IL- $1 \alpha$ and IL- 6 were stimulated to a lesser extent $(12 \pm 2$ and $2 \pm 1 \mathrm{ng} / \mathrm{ml}$, respectively). Live $B$. burgdorferi induced significantly more IL- $\beta(P<0.01)$ and TNF $(P<0.001)$ than sonicated $B$. burgdorferi or LPS. Synthesis of IL- $1 \alpha$, IL- 6 , and IL-1 ra induced by all three stimuli was similar. Unexpectedly, live $B$. burgdorferi stimulated fivefold more IL- $1 \beta$ than IL- $1 \alpha(P<0.0001)$ and sevenfold more IL- $1 \beta$

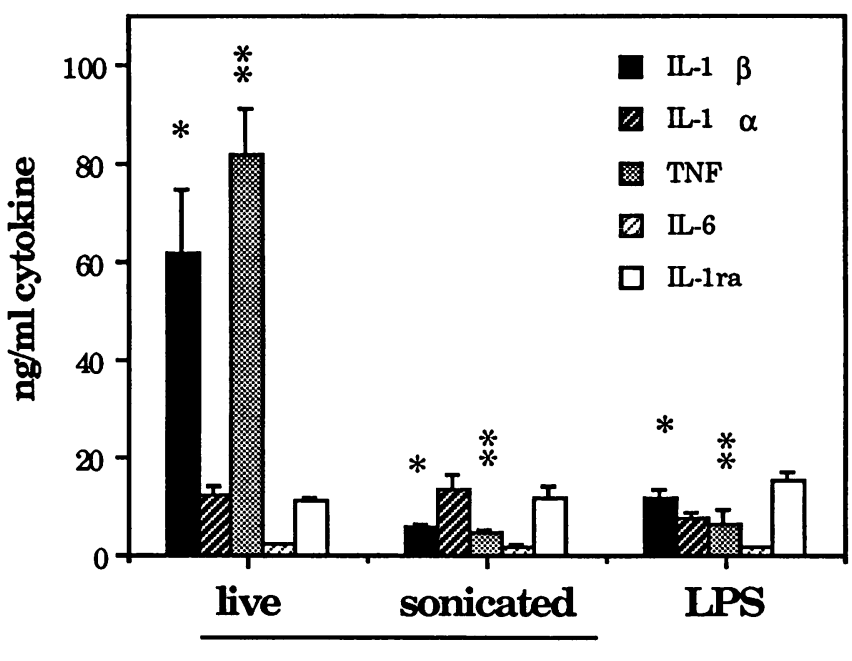

B. burgdorferi

Figure 1. Induction of IL-1 $\beta$, IL- $1 \alpha$, TNF, IL-6, and IL-1 ra by live $B$. burgdorferi (LP 297), sonicated B. burgdorferi, or LPS. PBMC from 23 donors were cultured for $24 \mathrm{~h}$, and the resulting supernatants tested in cytokine-specific RIAs. Live $B$. burgdorferi induced significantly more IL-1 $\beta\left({ }^{*} P<0.01\right)$ and TNF $\left({ }^{* *} P<0.001\right)$ than the amounts induced by sonicated $B$. burgdorferi or LPS. 


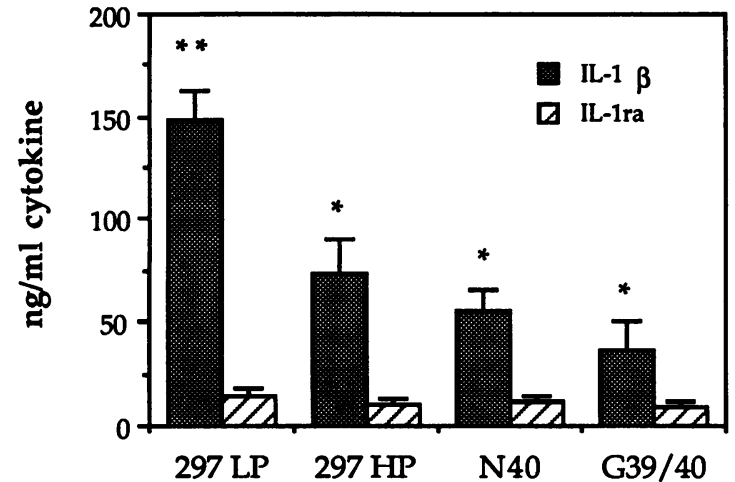

Figure 2. Induction of IL-1 $\beta$ and IL-1 ra by four preparations of $B$. burgdorferi, strains 297 (LP and HP), N40, and G39/40. Data are mean \pm SEM of six donors. Significantly more IL- $1 \beta$ was induced by the virulent strain 297 LP compared to the other three strains (** vs. *, $P<0.001)$; no strain differences in IL-1 ra induction were seen.

than IL-1 ra $(P<0.001)$. In contrast, the ratios of IL-1 $\beta$ to IL- $1 \alpha$ and IL- $1 \beta$ to IL-1 ra induced by sonicated $B$. burgdorferi or LPS were close to 1 .

Strain differences and Borrelial factors. Because of the markedly high levels of IL- $1 \beta$ induced by LP 297 live $B$. burgdorferi, the cytokine-inducing capacity of other strains was also tested. LP 297 live $B$. burgdorferi induced 148 $\pm 16 \mathrm{ng} / \mathrm{ml}$ IL-1 $\beta$, significantly more than the avirulent strains HP 297, N40, or G39/40 ( $P<0.001)$ (Fig. 2). However, no difference was observed in the amount of IL-1 ra induced by these strains.

To elucidate further the microbial factor(s) responsible for the preferential induction of IL- $1 \beta$, four preparations of live vs. heat-treated $B$. burgdorferi were compared. Heating significantly decreased induction of IL- $1 \beta$ by all four $B$. burgdorferi preparations $(P<0.05)$ (Fig. 3, left), whereas no differences were seen after heating in the induction of IL-1ra (Fig. 3, right).

The possibility that live B. burgdorferi, particularly LP 297, produced a soluble factor which could stimulate IL- $1 \beta$ production was investigated. Because BSK medium (which contains neopeptone, yeastolate, tryptone, gelatin, bovine serum albumin, and rabbit serum) is itself a potent inducer of cytokines (20-30 $\mathrm{ng} / \mathrm{ml}$ of IL- $1 \beta$ or TNF), we prepared spirochete-conditioned RPMI to test as a stimulant for cytokine induction.
Spirochete-conditioned RPMI was incubated with PBMC from four donors. Levels of IL-1 $\beta$, IL-1 ra, and TNF by this conditioned media were below limits of detection by RIAs (data not shown).

Because immunoaffinity purified $B$. burgdorferi lipoproteins (including a mixture of Osp A and B) induce TNF (23), the contribution of Osp B, a major outer surface protein of $B$. burgdorferi, to the induction of IL- $1 \beta$ and IL-1 ra was then examined (Fig. 4). At the highest concentrations tested, Osp B induced $1.0 \pm 0.2 \mathrm{ng} / \mathrm{ml}$ of IL- $1 \beta$, whereas at lower concentrations, Osp B induced $<0.10 \mathrm{ng} / \mathrm{ml} \mathrm{IL-1} \beta$. In contrast, the highest concentration of Osp B tested induced $4.1 \pm 1.1 \mathrm{ng} / \mathrm{ml}$ IL-1 ra, whereas lower concentrations induced $1-2 \mathrm{ng} / \mathrm{ml}$. Polymyxin B had no effect on the response to this stimulus. Thus, Osp B made little contribution to the marked induction of IL- $1 \beta$, but could contribute to some extent to induction of IL-1 ra.

Secretion of $I L-1 \alpha, I L-1 \beta$, and $I L-1 r a$. The proportions of cell-associated vs. secreted IL- $1 \alpha$, IL- $1 \beta$, and IL-1 ra induced by five spirochetes per PBMC (live LP 297) were compared to those induced by LPS $(10 \mathrm{ng} / \mathrm{ml})$ in PBMC of 18 donors. After stimulation with $B$. burgdorferi, $34 \pm 2 \%$ of total IL- $\alpha$ and $78 \pm 1 \%$ of total IL- $1 \beta$ were secreted. After LPS stimulation, $21 \pm 4 \%(P=0.01)$ of IL- $1 \alpha$ and $63 \pm 3 \%$ of total IL- $1 \beta(P$ $<0.001)$ were secreted. No differences were seen in the amounts or proportions of secreted IL-1 ra induced by $B$. burgdorferi or LPS $(72 \pm 3 \%$ and $76 \pm 5 \%)$.

Dose-dependent effect of $B$. burgdorferi on cytokine production. Increasing the number of spirochetes (live LP 297) per PBMC (from 0.08 to 60 organisms per PBMC) resulted in a dose response for IL- $1 \beta$ synthesis (Fig. 5, top). In contrast, increasing the number of spirochetes from 0.08 to 0.74 per PBMC resulted in a shallow dose-response curve for IL-1 ra, which reached a plateau thereafter despite an increase to 60 spirochetes per PBMC. No dose response was seen for IL- $1 \alpha$. The ratio of IL-1 $\beta$ to IL-1 ra increased to 14:1 (inset). When LPS $(0.001-1000 \mathrm{ng} / \mathrm{ml})$ was used as a stimulus, production of IL- $1 \beta$ and IL- 1 ra increased to maximal amounts in response to $10 \mathrm{ng} / \mathrm{ml}$ LPS, then decreased at higher concentrations (Fig. 5 , bottom). The ratio of IL- $1 \beta$ to IL-1 ra increased to a maximum at a concentration of $1 \mathrm{ng} / \mathrm{ml}$ LPS, then remained at a plateau (inset). IL-1 $\alpha$ production increased linearty in response to LPS concentrations from 0.001 to $0.10 \mathrm{ng} / \mathrm{ml}$, then


Figure 3. Induction of IL-1 $\beta$ ( left) and IL-1 ra (right) by paired samples of four preparations of live or heated $B$. burgdorferi in PBMC from five donors. For all preparations of $B$. burgdorferi, heating significantly decreased the synthesis of IL-1 $\beta$ (all pairs, $P<0.05$ ), but had no effect on induction of IL-1 ra. 


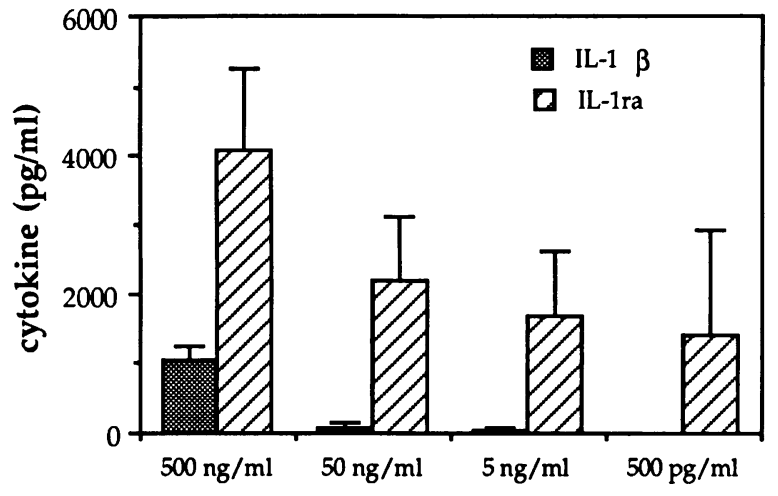

[Osp B]

Figure 4. Induction of IL- $1 \beta$ and IL-1 ra by recombinant Osp B protein. Log dilutions of recombinant Osp B were incubated with PBMC of four donors ( mean \pm SEM).

remained unchanged despite increasing the concentration of LPS to $1,000 \mathrm{ng} / \mathrm{ml}$.

Kinetics of $I L-1 \beta, I L-1 \alpha$, and IL-1ra synthesis. No differences were seen in the time of production of IL- $1 \alpha$ or IL-1 ra induced by LP 297 B. burgdorferi or LPS (Fig. 6). In contrast, by $4 \mathrm{~h}, B$. burgdorferi induced $24 \pm 5 \mathrm{ng} / \mathrm{ml}$ of IL- $1 \beta$, whereas
LPS induced $2 \pm 3 \mathrm{ng} / \mathrm{ml}(P<0.03)$. Compared to LPS, more striking differences in $B$. burgdorferi-induced IL- $1 \beta$ protein synthesis were seen at $12 \mathrm{~h}(95 \pm 18 \mathrm{vs} .23 \pm 13 \mathrm{ng} / \mathrm{ml}, P<0.01)$ and $24 \mathrm{~h}(109 \pm 6$ vs. $19 \pm 8 \mathrm{ng} / \mathrm{ml}, P<0.006)$. By $4 \mathrm{~h}, B$. burgdorferi induced the synthesis of more than fivefold more IL- $1 \beta$ than IL-1 ra, whereas no difference was seen in LPS-induced synthesis of IL- $1 \beta$ and IL- 1 ra. For both stimulants, ratios of IL-1 $\beta$ to IL-1 ra remained unchanged at 12 and $24 \mathrm{~h}$.

Accumulation of $m R N A$ for $I L-1 \beta$ and $I L-1 \mathrm{ra}$. The kinetics of steady-state IL-1 $\beta$ and IL-1 ra mRNA induced by LP $297 B$. burgdorferi or LPS were compared by Northern and dot blot analysis. Levels of mRNA for IL- $1 \beta$ and IL-1 ra were nondetectable in unstimulated cells. The time course for IL- $1 \beta$ mRNA levels were similar during the first $4 \mathrm{~h}$ after $B$. burgdorferi or LPS stimulation; IL- $1 \beta$ mRNA accumulation reached a peak at $4 \mathrm{~h}$ (Fig. 7). Protein production showed eightfold more IL- $1 \beta$ stimulated by $B$. burgdorferi compared to LPS at $4 \mathrm{~h}$ ( 17 vs. $2.1 \mathrm{ng} / \mathrm{ml}$ ). In a longer time course study, IL-1 $\beta$ mRNA reached a peak at $3 \mathrm{~h}$ and declined until $12 \mathrm{~h}$ after stimulation by $B$. burgdorferi or LPS (Fig. $8 A$ ). However, IL- $1 \beta$ mRNA levels again increased $18 \mathrm{~h}$ after exposure to $B$. burgdorferi, and remained elevated at $24 \mathrm{~h}$. In contrast, LPS-induced IL- $\beta$ mRNA continued to decline until 24 h. B. burgdorferi-induced IL-1 $\beta$ protein continued to rise at $24 \mathrm{~h}$; LPS-induced IL- $1 \beta$ protein reached near-peak levels by $6 \mathrm{~h}$.
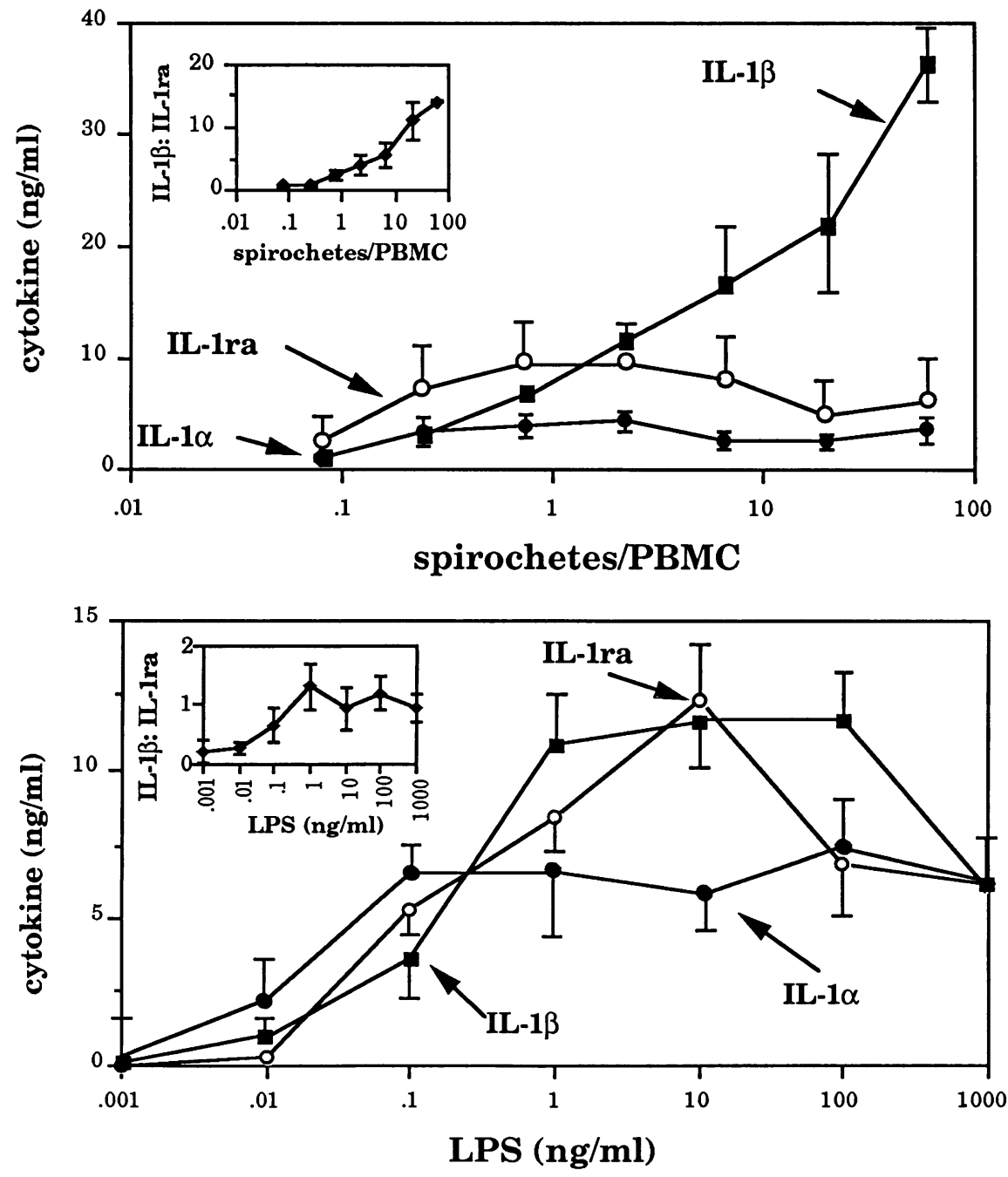

Figure 5. Dose-dependent effect of $B$. burgdorferi on the synthesis of IL-1 $\beta$. (Top) Synthesis of IL- $1 \beta$, IL- $1 \alpha$, and IL- 1 ra in response to increasing numbers of live spirochetes per PBMC. (Bottom) Synthesis of IL-1 $\beta$, IL- $1 \alpha$, and IL-1 ra in response to increasing concentrations of LPS. Data are mean \pm SEM of six donors. Insets show the ratios of IL- $1 \beta$ to IL1 ra over these different concentrations of stimuli. 
$\mathbf{A}$

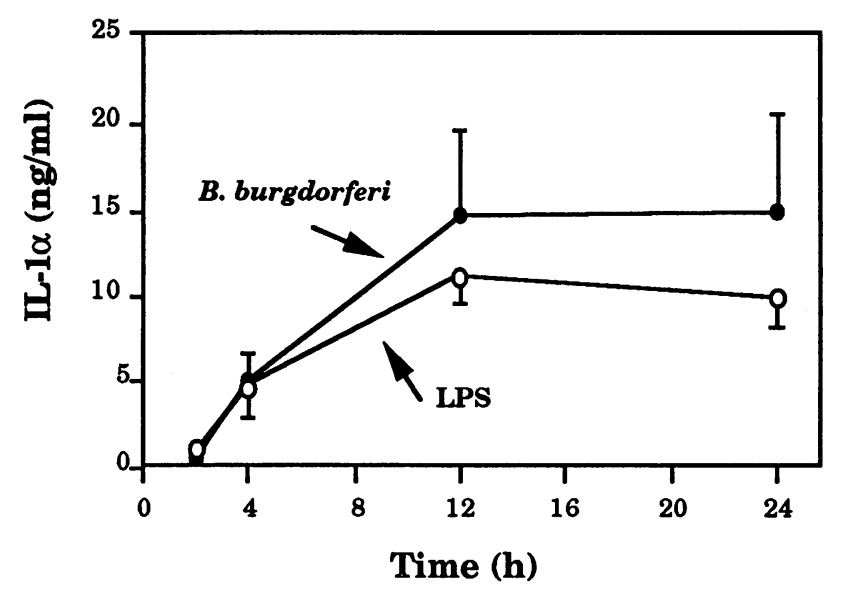

B

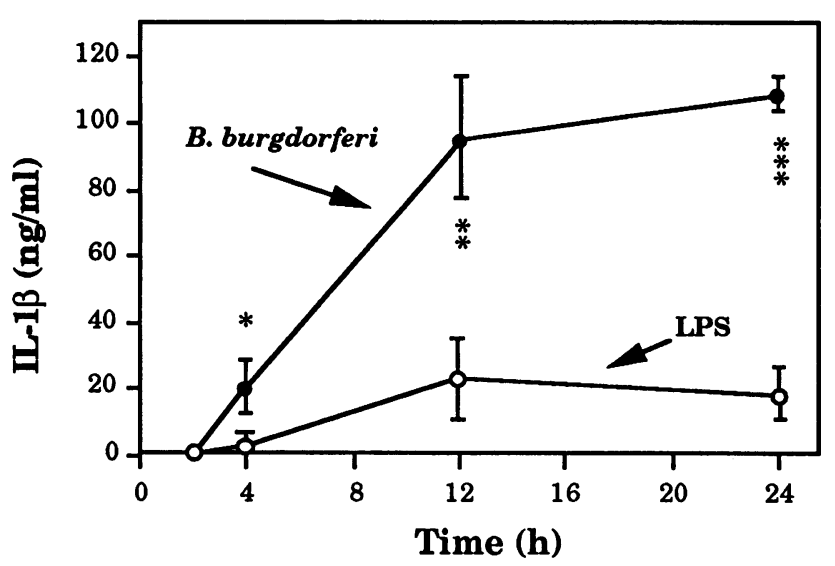

C

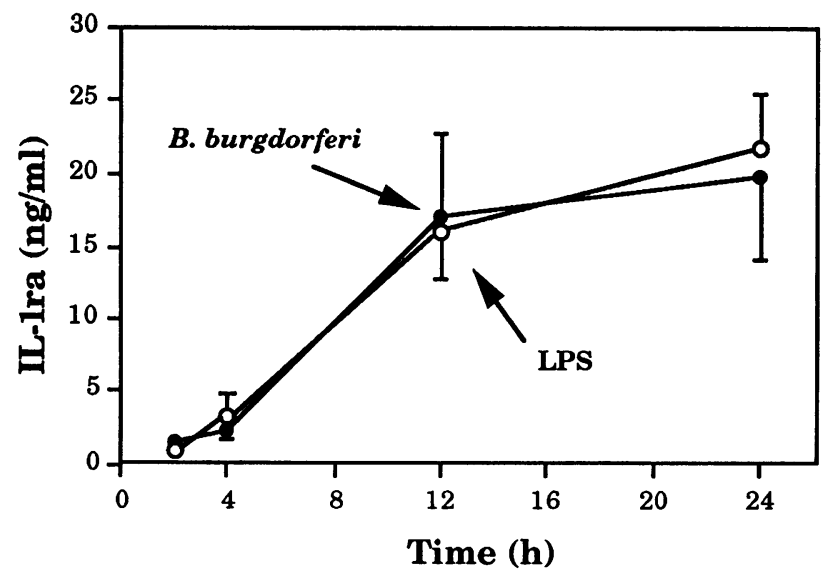

Figure 6. Kinetics of production of IL- $1 \alpha$, IL- $1 \beta$, and IL-1 ra in response to live $B$. burgdorferi or LPS. Data (mean \pm SEM) for three donors are shown. No differences were seen in the kinetics of production of IL- $1 \alpha$ or IL-1 ra, whereas significantly more IL- $1 \beta$ was induced by live $B$. burgdorferi at 4,12 , and $24 \mathrm{~h}$ than LPS $\left({ }^{*} P<0.03\right.$, ${ }^{* *} P<0.01$, and $\left.{ }^{* * *} P<0.006\right)$.

Similar to IL- $1 \beta$ mRNA, the accumulation of IL-1 ra mRNA induced by $B$. burgdorferi or LPS were comparable until $4 \mathrm{~h}$ (data not shown). Thereafter, LPS-induced IL-1 ra

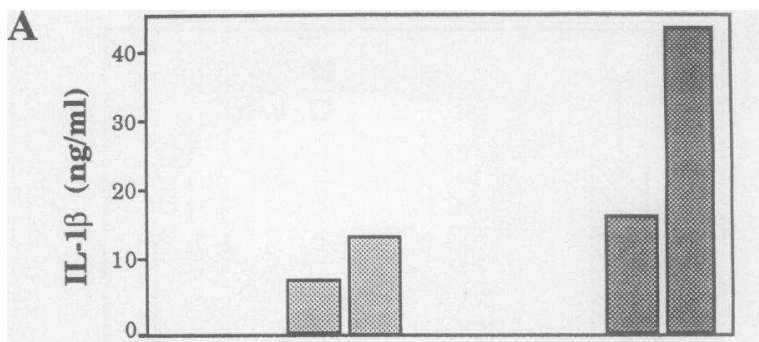

$\mathbf{B}$

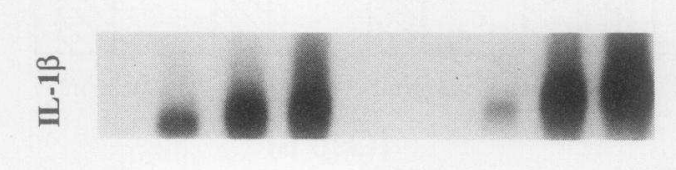

C

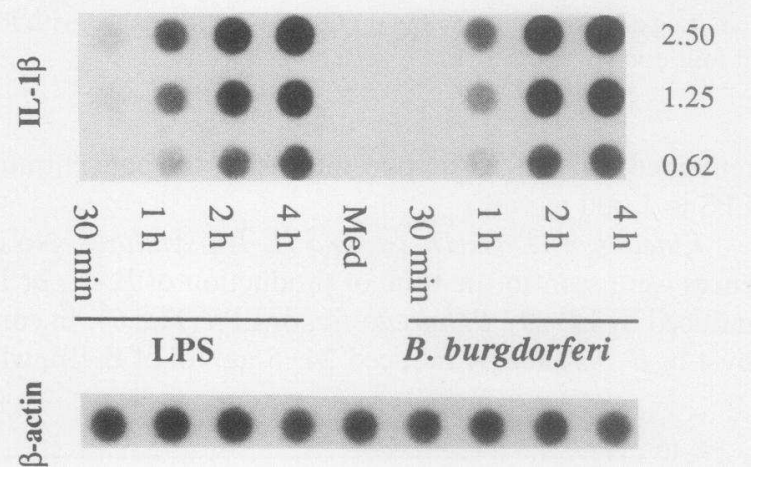

Figure 7. Early kinetics of IL-1 $\beta$ protein and mRNA induced by LPS and $B$. burgdorferi. $(A)$ The synthesis of IL- $1 \beta$ protein at $30 \mathrm{~min}$ and 1,2 , and $4 \mathrm{~h} .(B)$ The corresponding IL- $\beta$ mRNA. $(C)$ The same blot probed for $\beta$-actin.

mRNA continued to increase until reaching peak levels at $9 \mathrm{~h}$, then decreasing gradually until $24 \mathrm{~h}$ (Fig. $8 B$ ). In contrast, $B$. burgdorferi-induced IL-1 ra mRNA peaked at $12 \mathrm{~h}$, and then gradually declined. No difference in IL-1 ra protein induced by the two stimuli was seen over $24 \mathrm{~h}$.

\section{Discussion}

By using specific RIAs, we have shown a remarkable preferential induction of IL- $1 \beta$ and TNF by $B$. burgdorferi. Unlike LPS, live $B$. burgdorferi preferentially induced IL- $1 \beta$ over the IL-1 ra, as well as IL-1 $\alpha$. This selectivity was most dramatic when the virulent strain LP297 was used. Habicht et al. (24) reported that $B$. burgdorferi stimulate marked IL-1 biologic activity from murine macrophages, P388D1 cells, and human PBMC. However, they used nonspecific fibroblast and $T$ cell proliferation assays which do not distinguish between IL- $1 \beta$ and IL- $1 \alpha$, and may respond to other cytokines such as IL-2, IL-4, IL-6, or TNF, alone or in combination (25-27). Furthermore, it is known that the bioassays for IL-1 are affected by cytokine antagonists such as IL-1 ra and soluble cytokine receptors (28-30).

The present studies show that the component(s) of $B$. burgdorferi associated with the preferential induction of IL- $1 \beta$ is heat resistant but eliminated during the sonication procedure. We were unable to demonstrate that spirochete-conditioned 

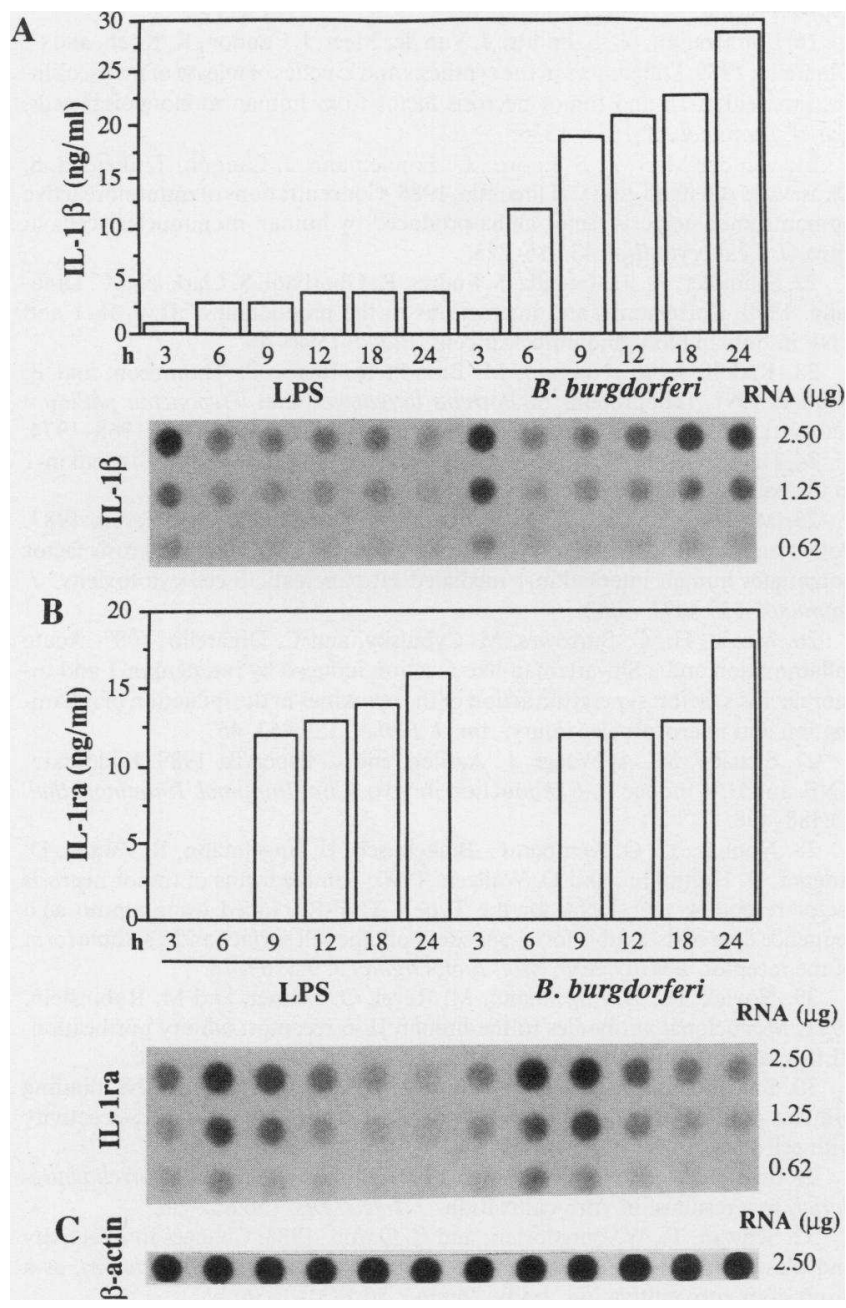

Figure 8. Late kinetics of IL- $1 \beta$ protein and mRNA induced by LPS and $B$. burgdorferi. $(A)$ The synthesis of IL- $1 \beta$ protein at $3,6,9,12$, 18 , and $24 \mathrm{~h}$, with the corresponding levels of IL- $1 \beta$ mRNA shown by dilutional analysis below. $(B)$ IL-1 ra protein and mRNA induced by LPS and $B$. burgdorferi. ( $C$ ) The same blot probed for $\beta$-actin.

medium contained soluble borrelial product( $\mathrm{s}$ ) which induced IL-1 $\beta$. Therefore, we conclude that the component(s) of $B$. burgdorferi responsible for IL- $1 \beta$ induction resides in the cell wall, and is not readily secreted, but rather is associated with the structural integrity of the wall. This suggests a requirement for intact cells. Although one could speculate that such a putative spirochetal wall structure satisfies a simple "particulate size" requirement for monocyte stimulation, the data on strain and passage differences suggest another mechanism. The component(s) which preferentially trigger IL- $1 \beta$ gene expression and protein synthesis may be a complex of components which varies among strains and/or is lost with repeated in vitro passage of B. burgdorferi. Extensive passage of strain 297 renders the spirochete noninfectious (18) and as we show, its ability to induce high levels of IL-1 $\beta$. Preferential induction of IL-1 $\beta$ over IL-1 ra may relate to infectivity and production of disease in vivo.

The onset of chronic arthritis in Lyme disease coincides with the appearance of a humoral immune response to Osp A and Osp B (6). Furthermore, Osp B may be lost during serial laboratory passage of $B$. burgdorferi; in some strains, this corre- sponds to loss of infectivity in mice $(31,32)$. We found that recombinant Osp B induced little IL-1 $\beta$.

The relative synthesis of the related but distinct genes IL$1 \beta$, IL- $1 \alpha$, and IL- 1 ra is stimulus dependent $(12,33,34)$. Soluble stimuli such as LPS, phytohemagglutinin, and toxic shock syndrome toxin-1 induce nearly equal amounts of IL- $1 \alpha$, IL$1 \beta$, and TNF ( $5-15 \mathrm{ng} / \mathrm{ml})$ with somewhat more IL- $1 \alpha$ produced by most donors $(35,36)$. Particulate stimuli such as Staphylococcus epidermidis induce threefold more IL-1 $\beta$ than IL- $1 \alpha$. However, there appears to be more IL- 1 ra than IL- $1 \beta$ synthesized by PBMC using various stimuli (37). Soluble IgG or granulocyte/macrophage colony-stimulating factor induce IL-1 ra but not IL- $1 \alpha$ or IL-1 $\beta$ (12-14). More IL-1 ra than IL-1 is found in children with systemic juvenile rheumatoid arthritis (38). In experimental human endotoxemia, at least 100 -fold more IL-1 ra is found in the circulation than IL- $1 \beta(15)$. Thus, live $B$. burgdorferi, of any stimuli studied to date, appears to be unique in its marked preferential activation of IL- $1 \beta$. In our dose-response experiments, increasing amounts of LPS induced parallel increases in IL-1 $\beta$ and IL-1 ra. In contrast, $B$. burgdorferi induced larger amounts of the agonist IL-1 $\beta$ than the antagonist IL-1 ra. By $4 \mathrm{~h}$ after stimulation with $B$. burgdorferi, IL- $1 \beta$ protein exceeded IL-1 ra protein by greater than fivefold. Some reports suggest that a 10-50 molar excess of IL-1 ra is needed to inhibit 50\% of IL-1 binding to T cells (39). Changes in the relative proportions of cytokines and their antagonists in vivo at different sites in the body or different times after infection clearly has important biological implications.

The kinetics of IL-1 $\beta$ mRNA production induced by $B$. burgdorferi resemble the pattern observed with LPS (40) within the first $12 \mathrm{~h}$ after stimulation. Nonetheless, increased protein production is seen as early as $4 \mathrm{~h}$ after stimulation, suggesting that $B$. burgdorferi enhances translational efficiency of IL- $1 \beta$ rather than affecting transcription. The second peak of IL- $1 \beta \mathrm{mRNA}$ induced by $B$. burgdorferi may reflect failure of $B$. burgdorferi to induce a repressor which down-regulates or destabilizes this mRNA, as described after LPS or PMA stimulation (41).

We believe our findings are relevant to the pathogenesis of Lyme disease. Early in the illness, low-grade fever, malaise, and marked fatigue are common symptoms, which may be mediated by IL-1 and other cytokines (42). However, the specific immune response to the organism seems to be suppressed early in the illness, and patients commonly experience only vague joint pain despite the presumed early spread of $B$. burgdorferi to synovial tissue. After several months, as the specific cellular and humoral immune responses expand to multiple spirochetal polypeptides, patients have brief attacks of arthritis in large joints (43).

Alterations in the balance of cytokines and their antagonists are likely involved in the sudden turning on and off of the inflammatory response in these patients, but the mechanisms controlling such alterations are not yet known. At the time of maximal expansion of the immune response, which usually occurs during the second or third years of illness, a genetically susceptible subset of patients, particularly those with HLADR4, may develop chronic arthritis (4). As in rheumatoid arthritis, erosion of cartilage and bone with elevated levels of collagenase and $\mathrm{PGE}_{2}$ may occur (5). The preferential induction by $B$. burgdorferi of the agonist IL- $1 \beta$, over the antagonist IL-1 ra, may contribute to the destructive lesion of Lyme arthritis. 


\section{Acknowledgments}

The contributions of B. Reinhardt, J. Mitchell, Dr. J. G. Schaller, and Dr. M. S. Klempner are gratefully acknowledged. This work was supported in part by the Charles A. Hood Foundation and Massachusetts Arthritis Foundation (Dr. Miller), and National Institutes of Health grants AR-20358 and AR-40576 (Dr. Steere) and AI-15614 (Dr. Dinarello).

\section{References}

1. Steere, A. C., R. L. Grodzicki, A. N. Kornblatt, J. E. Craft, A. G. Barbour, W. Burgdorfer, G. P. Schmid, E. Johnson, and S. E. Malawista. 1983. The spirochetal etiology of Lyme disease. N. Engl. J. Med. 308:733-40.

2. Steere, A. C., R. T. Schoen, and E. Taylor. 1987. The clinical evolution of Lyme arthritis. Ann. Intern. Med. 107:725-31.

3. Steere, A., A. Gibosky, M. Patarroyo, R. Winchester, J. Hardin, and S. Malawista. 1979. Chronic Lyme arthritis: clinical and immunogenetic differentiation from rheumatoid arthritis. Ann. Intern. Med. 90:896-901.

4. Steere, A., E. Dwyer, and R. Winchester. 1990. Association of chronic Lyme arthritis with HLA-DR4 and HLA-DR2 alleles. N. Engl. J. Med. 323:219223.

5. Steere, A., C. Brinckerhoff, D. Miller, H. Drinker, E. Harris, and S. Malawista. 1980. Elevated levels of collagenase and prostaglandin $E_{2}$ from synovium associated with erosion of cartilage and bone in a patient with chronic Lyme arthritis. Arthritis Rheum. 23:591-9.

6. Kalish, R., J. Leong, and A. Steere. 1991. Delay in the immune response to outer-surface proteins (OSP) A and B of $B$. burgdorferi: correlation with arthritis and treatment failure in susceptible patients with Lyme disease. Arthritis Rheum. 34:S43. (Abstr.)

7. Arend, W., and J.-M. Dayer. 1990. Cytokines and cytokine inhibitors or antagonists in rheumatoid arthritis. Arthritis Rheum. 33:305-315.

8. Miller, L. C., and C. A. Dinarello. 1987. Biologic activities of interleukin-1 relevant to rheumatic diseases. Pathol. Immunopathol. Res. 6:22-36.

9. Eastgate, J. A., J. A. Symons, N. C. Wood, F. M. Grinlinton, F. S. diGiovine, and G. W. Duff. 1988. Correlation of plasma interleukin 1 levels with disease activity in rheumatoid arthritis. Lancet. ii:706-9.

10. Arend, W., H. Welgus, R. Thompson, and S. Eisenberg. 1990. Biological properties of recombinant human monocyte-derived interleukin 1 receptor antagonist. J. Clin. Invest. 85:1694-1697.

11. Eisenberg, S., R. Evans, W. Arend, E. Verderber, M. Brewer, C. Hannum, and $R$. Thompson. 1990. Primary structure and functional expression from complementary DNA of a human interleukin-1 receptor antagonist. Nature (Lond.). 343:341-346.

12. Arend, W., F. Joslin, R. Thompson, and C. Hannum. 1989. IL-1 inhibitor from human monocytes: production and characterization of biological activities. J. Immunol. 143:1851-1854.

13. Arend, W., M. Smith, R. Janson, and F. Joslin. 1991. IL-1 receptor antagonist and IL-1 $\beta$ production in human monocytes are regulated differently. J. Immunol. 147:1530-1536.

14. Poutsiaka, D., B. Clark, E. Vannier, and C. Dinarello. 1991. Production in interleukin- $1 \mathrm{ra}$ and interleukin- $\beta$ by peripheral blood mononuclear cells is differentially regulated. Blood. 78:1275-81.

15. Granowitz, E., A. Santos, D. Poutsiaka, J. Cannon, D. Wilmore, S. Wolff, and C. Dinarello. 1991. Production of interleukin-1 receptor antagonist during experimental endotoxaemia. Lancet. ii:1423-1424.

16. Endres, S., R. Ghorbani, V. Kelley, K. Georgilis, G. Lonnemann, J. Van der Meer, J. Cannon, T. Rogers, M. Klempner, P. Weber, et al. 1989. The effect of dietary supplementation with n-3 polyunsaturated fatty acids on the synthesis of interleukin-1 and tumor necrosis factor by mononuclear cells. N. Engl. J. Med. $320: 265-271$.

17. Schindler, R., and C. Dinarello. 1989. A method for removing interleukin-1 and tumor necrosis factor-inducing substances from bacterial cultures by ultrafiltration with polysulfone. J. Immunol. Methods. 116:159-165.

18. Georgilis, K., A. Steere, and M. Klempner. 1991. Infectivity of Borrelia burgdorferi correlates with resistance to elimination by phagocytic cells. J. Infect. Dis. 163:150-155.

19. Endres, S., R. Ghorbani, G. Lonnemann, J. van der Meer, and C. Dinarello. 1988. Measurement of immunoreactive interleukin- $1 \beta$ from human mononuclear cells: optimization of recovery, intrasubject consistency, and comparison with interleukin-1 $\alpha$ and tumor necrosis factor. Clin. Immunol. Immunopathol. 49:424-438.
20. Lonnemann, G., S. Endres, J. Van der Meer, J. Cannon, K. Koch, and C. Dinarello. 1989. Differences in the synthesis and kinetics of release of interleukin$1 \alpha$, interleukin- $1 \beta$ and tumor necrosis factor from human mononuclear cells. Eur. J. Immunol. 19:1531-1536.

21. van der Meer, J., S. Endres, G. Lonnemann, J. Cannon, T. Ikejima, S. Okusawa, J. Gelfand, and C. Dinarello. 1988. Concentrations of immunoreactive human tumor necrosis factor alpha produced by human mononuclear cells in vitro. J. Leukocyte Biol. 43:216-223.

22. Schindler, R., J. Mancilla, S. Endres, R. Ghorbani, S. Clark, and C. Dinarello. 1990. Correlations and interactions in the production of IL-6, IL-1 and TNF in human blood mononuclear cells. Blood. 75:40-46.

23. Radolf, J., M. Norgard, M. Brandt, R. Isaacs, P. Thompson, and B. Beutler. 1991. Lipoproteins of Borrelia burgdorferi and Treponema pallidum activate cachectin/tumor necrosis factor synthesis. J. Immunol. 147:1968-1974.

24. Habicht, G. S., G. Beck, and J. L. Benach. 1988. The role of interleukin-1 in the pathogenesis of Lyme disease. Ann. N. Y. Acad. Sci. 539:80-6.

25. Mandrup-Poulsen, T., K. Bendtzen, C. Dinarello, and J. Nerup. 1987. Potentiation of IL-1 mediated cell killing by TNF: human tumor necrosis factor potentiates human interleukin-1 mediated rat pancreatic $\beta$ cell cytotoxicity. $J$. Immunol. 139:4077-4082.

26. Movat, H., C. Burrowes, M. Cybulsky, and C. Dinarello. 1987. Acute inflammation and a Shwartzman-like reaction induced by interleukin- 1 and tumor necrosis factor: synergistic action of the cytokines in the induction of inflammation and microvascular injury. Am. J. Pathol. 129:463-467.

27. Shalaby, M., A. Waage, L. Aarden, and L. Espervik. 1989. Endotoxin, TNF, and IL-1 induce IL-6 production in vivo. Clin. Immunol. Immunopathol. 53:488-498.

28. Nophar, Y., O. Kemper, C. Brakebusch, H. Engelmann, R. Zwang, D. Aderka, H. Holtmann, and D. Wallach. 1990. Soluble forms of tumor necrosis factor receptors: the cDNA for the Type I TNF-R, cloned using amino acid sequence data of its soluble form, encodes both the cell surface and a soluble form of the receptor. EMBO (Eur. Mol. Biol. Organ.) J. 9:3269-78.

29. Novick, D., H. Engelmann, M. Revel, O. Leitner, and M. Rubinstein. 1991. Monoclonal antibodies to the human IL-6 receptor: affinity purification, ELISA, and inhibition of ligand binding. J. Chromatogr. 10:137-146.

30. Engelmann, H., D. Novick, and D. Wallach. 1990. Two TNF-binding proteins purified from human urine: evidence for immunological cross-reactivity with cell surface TNF receptors. J. Biol. Chem. 265:1531-1536.

31. Schwan, T., and W. Burgdorfer. 1987. Antigenic changes of Borrelia burgdorferi as a result of in vitro cultivation. J. Infect. Dis. 156:852-56.

32. Schwan, T., W. Burgdorferi, and C. Garon. 1988. Changes in infectivity and plasmid profile of the Lyme disease spirochete, Borrelia burgdorferi, as a result of in vitro cultivation. Infect. Immun. 56:1831-1836.

33. Dinarello, C. 1991. Interleukin-1 and interleukin-1 antagonism. Blood. 77:1627-1652.

34. Arend, W. 1991. Interleukin-1 receptor antagonist. J. Clin. Invest. 88:1445-1451.

35. Endres, S., J. Cannon, R. Ghorbani, T. Dempsey, S. Sisson, G. Lonnemann, J. Van der Meer, S. Wolff, and C. Dinarello. 1989. In vitro production of IL-1 $\beta$, IL-1 $\alpha$, TNF, and IL-2 in healthy subjects: distribution, effect of cyclooxygenase inhibition and evidence of independent gene regulation. Eur. J. Immunol. 19:2327-2333.

36. Ikejima, T., S. Okusawa, J. van der Meer, and C. Dinarello. 1988. Induction by Toxic-shock syndrome toxin-1 of a circulating tumor necrosis factor-like substance in rabbits and of immunoreactive tumor necrosis factor and interleukin-1 from human mononuclear cells. J. Infect. Dis. 158:1017-1025.

37. Dinarello, C., and R. Thompson. 1991. Blocking IL-1: interleukin 1 receptor antagonist in vivo and in vitro. Immunology Today. 12:404-409.

38. Prieur, A.-M., M.-T. Kaufmann, C. Griscelli, and J.-M. Dayer. 1987. Specific interleukin-1 inhibitor in serum and urine of children with systemic juvenile chronic arthritis. Lancet. ii:1240-1242.

39. Granowitz, E., B. Clark, J. Mancilla, and C. Dinarello. 1991. Interleukin-1 receptor antagonist competitively inhibits the binding of interleukin- 1 to the type II interleukin-1 receptor. J. Biol. Chem. 266:14147-14150.

40. Fenton, M., B. Clark, K. Collins, A. Webb, A. Rich, and P. Auron. 1987. Transcriptional regulation of the human prointerleukin-1 beta gene. J. Immunol. 138:3972-3979.

41. Fenton, M., M. Vermeulen, B. Clark, A. Webb, and P. Auron. 1988 Human prointerleukin-1 gene expression in monocytic cells is regulated by two distinct pathways. J. Immunol. 140:2267-2273.

42. Smith, J., W. Urba, R. Steis, J. Janik, B. Fenton, W. Sharfman, K. Conlon, M. Sznol, S. Creekmore, N. Wells, et al. 1990. Interleukin-1 alpha: results of a phase I toxicity and immunomodulatory trial. Am. Soc. Clin. Oncol. 9:717.

43. Steere, A. 1989. Lyme disease. N. Engl. J. Med. 321:586-596. 